\title{
Productive performance and efficiency of utilization of the diet components in dairy cows fed castor meal treated with calcium oxide ${ }^{1}$
}

\author{
Juliana Variz Cobianchi ${ }^{2}$, André Soares de Oliveira ${ }^{3}$, José Maurício de Souza Campos ${ }^{4}$, \\ Amanda Vasconcelos Guimarães ${ }^{5}$, Sebastião de Campos Valadares Filho ${ }^{6}$, Flávio Pereira \\ Cobianchi $^{7}$, Thalita Evani Silva de Oliveira ${ }^{8}$
}

\author{
${ }^{1}$ Supported by CNPq and FINEP. \\ ${ }^{2}$ Mestre em Zootecnia/UFV, Viçosa-MG, fellow student by CNPq. \\ ${ }^{3}$ Instituto de Ciências Agrárias e Ambientais da UFMT, Campus Sinop, Sinop-MT. Researcher at INCT-Ciência Animal/CNPq. \\ ${ }^{4}$ Universidade Federal Rural de Pernambuco, Unidade Acadêmica de Garanhuns. Researcher at CNPq. \\ ${ }^{5}$ Estudante de doutorado em Zootecnia/UFLA, Lavras-MG, Brazil. \\ ${ }^{6}$ Departamento de Zootecnia, Universidade Federal de Viçosa, Campus Viçosa. \\ ${ }^{7}$ Laticínios Bela Vista, Bela Vista de Goiás-GO, Brazil. \\ ${ }^{8}$ Estudante de Medicina Veterinária/UNIVIÇOSA, Viçosa-MG, Brazil.
}

\begin{abstract}
The effect of replacing of $0 ; 0.33 ; 0.67$ and $1.0(\mathrm{~kg} / \mathrm{kg})$ of soybean meal (SBM) by undecorticated castor seed meal treated with calcium oxide (CMT $-60 \mathrm{~g} / \mathrm{kg}$ ) was evaluated on performance and efficiency of nutrient utilization in dairy cows. Sixteen Holstein and crossbred cows were distributed in four $4 \times 4$ latin squares. Animals received concentrated feed at a ratio of $1 \mathrm{~kg}$ for $3 \mathrm{~kg}$ of milk produced, in the natural matter. The diets had the same amount of nitrogen ( $150.4 \mathrm{~g}$ crude protein $/ \mathrm{kg} \mathrm{DM}$ ), containing $325.6 \mathrm{~g}$ of concentrated feed $/ \mathrm{kg}$ DM. There was no effect on the serum concentration of transaminase and the animals showed no clinical symptoms of intoxication by ricin. The intake of DM, crude protein (CP) and non-fibrous carbohydrates (NFC) reduced from 0.67 replacement of SBM by CMT. The intake of neutral detergent fibers corrected for ash and protein (NDFap) increased from 0.33 replacement of SBM with CMT. Although the digestibility of dietary components decreased from 0.33 replacement, the intake of digestible components only reduced from 0.67 replacement. Because of the reduction of digestible energy, the synthesis of microbial CP and the utilization efficiency of rumen-degradable protein for the synthesis of microbial CP reduced with full replacement of SBM by CMT. Milk yield, milk composition, daily variation of body weight and the efficiency of utilization of the nutrients for the synthesis of $\mathrm{N}$ in milk reduced from 0.67 replacement of SBM by CMT. Castor seed meal treated with calcium oxide can replace up to 0.33 of SBM (50 g/kg DM diet DM) in the diet of dairy cows with an average milk production of $20 \mathrm{~kg} / \mathrm{day}$.
\end{abstract}

Key Words: digestibility, intake, milk production, nitrogenous compounds, ricin, Ricinus communis L.

\section{Introduction}

The expected growth of the participation of biodiesel in the world energy matrix has generated opportunities for the ruminant production because of the possibility of utilizing byproducts resulting from the process of extraction of oil from oilseeds. Among the cultures available, the castor oil seed (Ricinus communis L.) stands out for the potential of exploitation in regions not included in the economic development process and by the greater intensity in the use of labor force.

Despite the potential of utilization in the feeding of dairy cows (Robb et al., 1974; Matos, 1976), the castor seed meal and cake have been utilized exclusively as organic fertilizers, due to the presence of a powerful toxin (ricin), which reduces the competitiveness in relation to the other oilseeds (Oliveira et al., 2010a; Oliveira et al., 2010b).
Ricin is a protein found mainly in the endosperm of castor seeds and irreversibly inactivates eukaryotic ribosomes, inhibiting the synthesis of protein (Olsnes et al., 1974; Endo \& Tsurugi, 1988). It is composed of two subunits of different biological functions. Subunit A (36 kDa) inactivates specifically and irreversibly the eukaryotic ribosomes, impeding the protein synthesis; subunit B (29 kDa), in turn, is bound to the cell membrane and to subunit A, and allows the entrance of the latter into the cytosol by endocytosis (Olnes et al., 1974; Endo \& Tsurugi, 1988).

Although some detoxification methods have been known since the end of the decade of 1940 (Borchers, 1949; Kodras et al., 1949; Gardner et al., 1960), only recently has some more conclusive study been developed, in which only the use of autoclave (15 psi, $90 \mathrm{~min}$ ) or the treatment with calcium oxide or calcium hydroxide $(60 \mathrm{~g} / \mathrm{kg}$ castor meal) provoked complete denaturation of the toxin (Oliveira et al., 2007). 
The procedure of detoxification with calcium oxide suggested by Oliveira al. (2007) showed to be operationally simple, and with great economic viability. However, before recommending its use for animal feeding, studies of validation must be conducted, covering the evaluation of markers of nutritional efficiency, health and animal performance, which are still scarce for dairy cows. It has been hypothesized that undecorticated castor meal treated with 60 grams calcium oxide/ $\mathrm{kg}$ (CMT) can be utilized in replacement of soybean meal (SBM) in diets for dairy cows without affecting the utilization efficiency of the diet components or productive performance or causing alterations in the liver functions.

Therefore, the objective of this study was to evaluate the effect of replacing SBM by CMT $(0 ; 0.33 ; 0.67$ and $1.00 \mathrm{~kg} / \mathrm{kg}$, on a dry matter basis) on the serum concentration of liver enzymes, the intake and digestibility of the components of the diet, productive performance and metabolism of nitrogenous compounds $(\mathrm{N})$ in dairy cows with average milk yield of $20 \mathrm{~kg} /$ day.

\section{Material and Methods}

The experiment was conducted at the Unidade de Ensino, Pesquisa e Extensão, Departamento de Zootecnia of Universidade Federal de Viçosa. Sixteen purebred and crossbred Holstein cows (milk yield of $20.3 \pm 7.3 \mathrm{~kg}$ /day; body weight of $540 \pm 64 \mathrm{~kg} ; 100 \pm 73$ days of lactation) were distributed in four $4 \times 4$ Latin squares according to the period of lactation, balanced for residual effect. At the end of the experiment, all cows presented fewer than 150 days of gestation.
The experiment was comprised of four 21-day periods; the first 15 days were utilized for animals to adapt to the diets, and the rest, for data collection. Animals were fed four experimental diets referring to four levels of replacement of SBM by CMT: $0 ; 0.33 ; 0.67$; and $1.0 \mathrm{~kg} / \mathrm{kg}$, on a DM basis.

The inactivation of the ricin from the undecorticated castor seed meal (CM) was performed by denaturation with alkaline treatment, utilizing a $\mathrm{CaO}$ solution (agricultural micro-sprayed quicklime, containing 90\% total oxide, Mineração Belocal LTDA, São José da Lapa-Minas Gerais, Brazil), at the ratio of $1 \mathrm{~kg}$ in 10 liters of water, making up a dose of 60 grams of lime per $\mathrm{kg}$ of $\mathrm{CM}$, in the natural matter basis, as recommended by Oliveira et al. (2007). After mixing the $\mathrm{CM}$ with the lime solution, the material remained still for a period of twelve hours (overnight), and then was dried in the sun on a cemented yard for 48 hours.

Diets were formulated to contain the same amount of nitrogen, with $153.6 \mathrm{~g}$ crude protein $(\mathrm{CP}) / \mathrm{kg} \mathrm{DM}$, so as to meet the nutritional requirements of a cow weighing $540 \mathrm{~kg}$ body weight, producing milk at $25 \mathrm{~kg} /$ day and with $35 \mathrm{~g}$ fat $/ \mathrm{kg}$ milk (NRC, 2001). The mixture containing nine parts of urea and one part of ammonium sulfate was utilized to adjust the levels of crude protein of the diet. The animals received concentrate feed at the ratio of $1 \mathrm{~kg}$ for each $3 \mathrm{~kg}$ of milk produced, in the natural matter basis, which corresponded to a supply of diets containing $325.6 \mathrm{~g}$ concentrate/kg DM. Corn silage was utilized as the only source of forage (Table 1).

After previous analysis of the CP content of feedstuffs (Table 1), their proportion in the experimental diets was elaborated as described in Table 2. The mixture of

Table 1 - Chemical composition of the ingredients utilized in the experimental diets

\begin{tabular}{|c|c|c|c|c|c|}
\hline \multirow{2}{*}{ Items } & \multicolumn{5}{|c|}{ Feedstuffs } \\
\hline & Corn silage & Ground corn grain & Soybean meal & Wheat bran & $\mathrm{CMT}^{1}$ \\
\hline Dry matter (DM), g/kg & 240.1 & 884.4 & 877.8 & 888.6 & 908.4 \\
\hline Organic matter, g/kg DM & 952.7 & 986.3 & 937.8 & 950.5 & 853.1 \\
\hline Ether extract, g/kg DM & 27.1 & 35.4 & 8.5 & 6.4 & 6.9 \\
\hline Crude protein, g/kg DM & 80.8 & 90.1 & 506.3 & 179 & 357.4 \\
\hline Rumen-degradable protein, g/kg DM ${ }^{2}$ & 63.3 & 27.4 & 254.1 & 151.6 & 156.7 \\
\hline Non-protein nitrogen, $\mathrm{g} / \mathrm{kg} \mathrm{TN}{ }^{3}$ & 719.4 & 160.7 & 94 & 224.2 & 199.4 \\
\hline NDIN, g/kg TN & 208.8 & 148.2 & 136.6 & 154.7 & 356 \\
\hline ADIN, g/kg TN & 162.4 & 6.7 & 19.5 & 20 & 67.5 \\
\hline NDF corrected for ash and protein, $\mathrm{g} / \mathrm{kg} \mathrm{DM}$ & 523.5 & 115.3 & 143.7 & 372.6 & 342.6 \\
\hline Non-fibrous carbohydrates, g/kg DM & 321.3 & 745.4 & 390.4 & 281.4 & 146.2 \\
\hline Acid detergent fiber (ADF), g/kg DM & 355.7 & 18.5 & 76.3 & 108.7 & 295.3 \\
\hline Lignin $\mathrm{H}_{2} \mathrm{SO}_{4}, \mathrm{~g} / \mathrm{kg} \mathrm{DM}$ & 44.7 & 19.5 & 17.2 & 25.5 & 46.9 \\
\hline Cutin, g/kg DM & 28.6 & 0.3 & 6.7 & 18.1 & 212.4 \\
\hline Indigestible NDF, g/kg DM ${ }^{3}$ & 301.3 & 18.3 & 42.1 & 162.8 & 403.4 \\
\hline Indigestible $\mathrm{ADF}, \mathrm{g} / \mathrm{kg} \mathrm{DM}{ }^{3}$ & 166.8 & 11.9 & 4.6 & 95.6 & 339.9 \\
\hline
\end{tabular}

${ }^{1} \mathrm{CMT}$ - castor seed meal treated with $60 \mathrm{~g}$ calcium oxide/kg, according to Oliveira et al. (2007).

${ }^{2}$ Estimated according to the NRC (2001).

${ }^{3}$ Obtained after in situ rumen incubation for 264 hours (Casali, 2006).

TN - total nitrogenous compounds; NDIN - neutral detergent insoluble nitrogen; ADIN - acid detergent insoluble nitrogen. 
macrominerals was balanced to meet the total nutritional requirements, according to the NRC (2001).

The concentrated feed was mixed in the beginning of each period, and each feedstuff was sampled. Animals were managed in individual tie-type stalls, where they received feed ad libitum twice daily, at $7 \mathrm{~h} 00$ and $16 \mathrm{~h} 00$. In the collection period, twice daily, the quantities of corn silage supplied and leftovers were weighed and sampled, and the amount of concentrate feed supplied was weighed. Samples were stored at $-15^{\circ} \mathrm{C}$ for subsequent chemical analyses.

Feces were collected daily from the rectal ampulla once daily, at $8 \mathrm{~h} 00,10 \mathrm{~h} 00,12 \mathrm{~h} 00,14 \mathrm{~h} 00$ and $16 \mathrm{~h} 00$, from the 16th to the 20th days of each experimental period. Daily samples of feces from each animal, in each period, were stored at $-15{ }^{\circ} \mathrm{C}$ for subsequent drying and chemical analyses.

Samples of corn silage and feces were dried in forcedventilation oven $\left(60^{\circ} \mathrm{C}\right.$ for 72 hours $)$ and, along with those of feedstuffs, processed in knife mill with $1 \mathrm{~mm}$ mesh sieve for chemical analyses, and with $2 \mathrm{~mm}$ mesh for in situ rumen incubation. Composite samples were made from the air-dried daily samples of feces from each animal, in each period, for subsequent chemical analysis.
The determination of the concentration of ricin in the non-treated castor seed meal $(\mathrm{CM})$ and that treated with calcium oxide (CMT) was done through separation of fractions A (36 kDa) and B (29 kDa) by electrophoresis gel over $10 \%$ polyacrylamide in denaturing condition (SDSPAGE) according to the methodology proposed by Laemmli (1970) and by densitometric analysis of the crude protein extracts according to Oliveira et al. (2010a).

The analyses of the contents of DM, crude protein (total nitrogen $\times 6.25$ ), acid detergent fiber (ADF) and lignin $\left(\mathrm{H}_{2} \mathrm{SO}_{4} 720 \mathrm{~g} / \mathrm{g}\right)$ were conducted according to methods described in Silva \& Queiroz (2002). The quantification of cutin was done through hydrolysis of the residue of ADF with $\mathrm{H}_{2} \mathrm{SO}_{4} 720 \mathrm{~g} / \mathrm{g}$, followed by oxidation of the residue of hydrolysis with $\mathrm{KMnO}_{4}$ and burning in a muffle at $550{ }^{\circ} \mathrm{C}$, as described by Van Soest (1994). For the analysis of the concentration of neutral detergent fiber (NDF), samples were treated with thermostable alpha-amylases without sodium sulfite, corrected for the ash residue (Mertens, 2002) and for the residue of nitrogenous compounds (Licitra et al., 1996). Analyses of NDF and ADF were conducted in Ankom ${ }^{\circledR}$ extraction chambers with TNT (non-woven textile) bags (Valente, 2010) of dimensions $5 \times 5 \mathrm{~cm}$, keeping an

Table 2 - Proportion of ingredients and average chemical composition of the diets containing different levels of replacement of soybean meal by treated castor seed meal ${ }^{1}$

\begin{tabular}{|c|c|c|c|c|}
\hline \multirow{2}{*}{ Itens } & \multicolumn{4}{|c|}{ Level of replacement of soybean meal by castor seed meal $(\mathrm{kg} / \mathrm{kg})$} \\
\hline & 0.00 & 0.33 & 0.67 & 1.00 \\
\hline Corn silage, $\mathrm{g} / \mathrm{kg} \mathrm{DM}$ & 674.4 & 674.4 & 674.4 & 674.4 \\
\hline Ground corn grain, $\mathrm{g} / \mathrm{kg} \mathrm{DM}$ & 89.3 & 89.3 & 89.3 & 89.3 \\
\hline Wheat bran, g/kg DM & 67 & 63.5 & 60.2 & 56.8 \\
\hline Soybean meal, g/kg DM & 148.8 & 99.3 & 49.6 & 0 \\
\hline Treated castor seed meal, g/kg DM & 0 & 49.6 & 99.3 & 148.8 \\
\hline Urea and ammonium sulfate $(9: 1), \mathrm{g} / \mathrm{kg} \mathrm{DM}$ & 0.9 & 4.3 & 7.7 & 11.2 \\
\hline Mineral mix, g/kg DM & 13 & 13 & 13 & 13 \\
\hline Sodium chloride, $\mathrm{g} / \mathrm{kg}$ DM & 4.7 & 4.7 & 4.7 & 4.7 \\
\hline Potassium chloride, $\mathrm{g} / \mathrm{kg} \mathrm{DM}$ & 0.9 & 0.9 & 0.9 & 0.9 \\
\hline Sulfur flower, $\mathrm{g} / \mathrm{kg} \mathrm{DM}$ & 0.9 & 0.9 & 0.9 & 0.9 \\
\hline \multicolumn{5}{|l|}{ Chemical composition } \\
\hline Dry matter (DM), g/kg & 317.5 & 317.3 & 317.1 & 316.8 \\
\hline Organic matter, $\mathrm{g} / \mathrm{kg} \mathrm{DM}$ & 933.8 & 926.4 & 919.0 & 911.5 \\
\hline Ether extract, g/kg DM & 23.1 & 23.0 & 22.9 & 22.8 \\
\hline Crude protein, $\mathrm{g} / \mathrm{kg} \mathrm{DM}$ & 152.3 & 153.2 & 154.1 & 154.9 \\
\hline Rumen-degradable protein, g/kg DM & 95.6 & 99.0 & 102.6 & 106.1 \\
\hline Non-protein nitrogen, $\mathrm{g} / \mathrm{kg} \mathrm{TN}$ & 346.1 & 408.5 & 470.6 & 532.0 \\
\hline NDIN, g/kg TN & 162.3 & 179.6 & 196.7 & 213.5 \\
\hline ADIN, g/kg TN & 69.7 & 73.8 & 77.9 & 82.0 \\
\hline NDF corrected for ash and protein, $\mathrm{g} / \mathrm{kg} \mathrm{DM}$ & 409.7 & 418.3 & 426.9 & 435.5 \\
\hline Non-fibrous carbohydrates, g/kg DM & 350.2 & 338.8 & 327.5 & 316.1 \\
\hline Acid detergent fiber (ADF), g/kg DM & 260.2 & 270.7 & 281.2 & 291.7 \\
\hline Lignin $\mathrm{H}_{2} \mathrm{SO}_{4}, \mathrm{~g} / \mathrm{kg} \mathrm{DM}$ & 36.2 & 37.5 & 38.9 & 40.3 \\
\hline Cutin, g/kg DM & 21.5 & 31.7 & 41.8 & 52.0 \\
\hline Indigestible NDF, $\mathrm{g} / \mathrm{kg}$ DM & 222.0 & 239.4 & 256.8 & 274.1 \\
\hline Indigestible ADF, $\mathrm{g} / \mathrm{kg} \mathrm{DM}$ & 120.6 & 136.9 & 153.3 & 169.6 \\
\hline
\end{tabular}

${ }^{1}$ Castor seed meal treated with $60 \mathrm{~g}$ calcium oxide/kg, according to Oliveira et al. (2007).

NDIN - neutral detergent insoluble nitrogen; ADIN - acid detergent insoluble nitrogen; NDF - neutral detergent fiber; ADF - acid detergent fiber. 
average ratio of $14 \mathrm{mg}$ of $\mathrm{DM} / \mathrm{cm}^{2}$ of fabric and $100 \mathrm{~mL}$ of neutral detergent/g of air-dried sample. The quantification of non-protein nitrogen (NPN) of the feedstuffs was done according to Licitra et al. (1996).

The rumen-degradable protein content of the feedstuffs was calculated utilizing the equation $\mathrm{RDP}=\mathrm{a}+(\mathrm{b} \times \mathrm{kd}) /(\mathrm{kd}+\mathrm{kp})$, in which a $(\mathrm{g} / \mathrm{g})=$ soluble fraction, represented by the NPN fraction in the $\mathrm{TN} ; \mathrm{b}(\mathrm{g} / \mathrm{g})=$ potentially degradable insoluble fraction, represented by the fraction of rumen potentiallydegradable $\mathrm{N}$ of the TN (NDIN-ADIN); $\mathrm{kd}=$ degradation rate of fraction $\mathrm{b}$ in time $\mathrm{t}$, utilizing the values obtained by Oliveira (2008); $k p\left(h^{-1}\right)=$ the passage rate, calculated according to the equations described in the NRC (2001). The RUP content $(\mathrm{g} / \mathrm{g})$ was calculated as $1000-\mathrm{RDP}(\mathrm{g} / \mathrm{g})$, in which RDP = rumen-degradable protein; and RUP = rumenundegradable protein. The intake values of RDP and RUP were calculated by multiplying the DM intake by the RDP and RUP contents in the diet, respectively.

The contents of non-fibrous carbohydrates corrected for ash and protein $\left(\mathrm{NFC}_{\mathrm{ap}}\right.$ ) were calculated as proposed by Hall (2000), but adapted, as follows: $\mathrm{NFC}_{\mathrm{ap}}=100-$ $\left[(\mathrm{CP}-\mathrm{CP}\right.$ from urea + urea in the diet $)+\mathrm{NDF}_{\mathrm{ap}}+\mathrm{EE}+$ Ash]. The total digestible nutrients (TDN) were calculated with adaptations to the method described by Weiss (1999), through the following equation: $\mathrm{TDN}(\mathrm{g} / \mathrm{kg})=\mathrm{DCP}+$ $\mathrm{DNDF}_{\text {ap }}+\mathrm{DNFC}_{\mathrm{ap}}+2.25 \mathrm{DEE}$, in which DCP $=$ digestible crude protein; $\mathrm{DNDF}_{\mathrm{ap}}=$ digestible neutral detergent fiber; $\mathrm{DNFC}_{\mathrm{ap}}=$ digestible non-fiber carbohydrates; and DEE = digestible ether extract.

The total amount of fecal DM excreted was estimated by the concentration of indigestible acid detergent fiber (iADF), obtained after rumen incubation of the feedstuffs, leftovers and feces in polyester bags (Ankom ${ }^{\circledR}$, filter bag 57) for a period of 264 hours, according to Casali (2006).

Cows were milked mechanically twice daily, with milk production recorded from the 15 th to the 21 st days of each experimental period. Through a device attached to the milking machine, a sample of approximately $300 \mathrm{~mL}$ of milk was collected on the 18th and 19th days, in the morning and afternoon milking sessions, with composite samples made for each day according to milk yield. Two aliquots were taken from each sample: the first aliquot $(50 \mathrm{~mL})$ was conditioned in plastic bottles with preservative $\left(\right.$ Bronopol $^{\circledR}$ ), kept at between 2 and $6{ }^{\circ} \mathrm{C}$ and sent to the Laboratory of Analyses of Milk Quality of Embrapa Gado de Leite for determination of the contents of lactose, fat, total solids and nonfat total solids of the milk, according to the methodology described by the IDF (1996); the second aliquot was deproteinized with trichloroacetic acid $(10 \mathrm{~mL}$ of milk mixed with $5 \mathrm{~mL}$ trichloroacetic acid at $250 \mathrm{~g} / \mathrm{L}$ ), filtered through filter paper, determining the content of total nitrogen in the filtered solution (Silva \& Queiroz, 2002) and storing the rest at $-15{ }^{\circ} \mathrm{C}$ for subsequent analysis of allantoin. Milk yield (MY) corrected for $35 \mathrm{~g}$ fat $/ \mathrm{kg}$ of milk (MYC) was calculated according to Sklan et al. (1992).

On the seventh day of adaptation and at the end of each experimental period, animals were weighed individually for evaluation of variation of weight. Their weights corresponded to the averages of two weighing sessions, conducted before the supply of feeding and after milking sessions.

Blood samples were collected on the 18th day by coccygeal venipuncture, utilizing test tubes with anticoagulant (EDTA). Samples were immediately centrifuged at 5,000 rpm for 15 minutes, and then plasma samples were taken and conditioned in eppendorf tubes and frozen at $-15{ }^{\circ} \mathrm{C}$ for subsequent analyses of urea nitrogen concentration and measurement of liver enzymes gamma glutamyl transpeptidase (GGT), alanine aminotransaminase (ALT) and aspartate aminotransaminase (AST).

Spot samples of urine were obtained from all cows on the 17th day of each experimental period, during urination stimulated by vulva massage at three times: zero, four and eight hours after morning feeding. The urine was filtered and aliquots of $10 \mathrm{~mL}$ from each time were collected and diluted immediately in $40 \mathrm{~mL}$ sulfuric acid at $0.072 \mathrm{~N}$, to avoid bacterial destruction of the purine derivatives and precipitation of the uric acid, and stored at $-15^{\circ} \mathrm{C}$ for subsequent analyses of total nitrogen, urea, allantoin (AL), uric acid (UA) and creatinine. Immediately before analyses, samples from each time were thawed, centrifuged at 2,000 $\mathrm{xg}$ for 15 minutes, and then composite samples were formed (10 $\mathrm{mL}$ for each time) per cow in each period.

The analysis of the serum levels of GGT, AST and ALT were conducted via optimized kinetic method UV (commercial kits). Analyses of AL in the urine in the milk were done by colorimetry, according to Fujihara et al. (1987), described in Chen \& Gomes (1992). Analyses of urea were accomplished by the enzymatic-colorimetric system by the urease method, utilizing commercial kits (Labtest Diagnóstica S.A.). Analyses of uric acid in the urine were done via the Trinder enzymatic method, with the aid of commercial kits (Labtest Diagnóstica S.A.). The analyses of creatinine in the urine were done by the endpoint method with picrate and acidifier, utilizing commercial kits (Labtest Diagnóstica S.A.).

The daily urinary volume was estimated by dividing the daily urinary excretions of creatinine by the observed values of creatinine in the urine. The daily urinary excretion of creatinine was estimated from the proposition of $24.05 \mathrm{mg} / \mathrm{kg}$ live weight (LW) of creatinine (Chizzotti et al., 2008). 
The total excretion of purine derivatives (PD) was calculated by the sum of the amounts of allantoin and uric acid excreted in the urine and the amount of allantoin excreted in the milk, expressed in mmol/day. Absorbed purines (AP, mmol/ day) were calculated from the excretion of PD (PD, mmol/ day), through the equation: $\mathrm{PD}=0.85^{*} \mathrm{AP}+0.512 * \mathrm{LW}^{0.75}$, in which 0.85 is the recovery of absorbed purines as purine derivatives (Verbic et al., 1990) and $0.512 * \mathrm{LW}^{0.75}$ is the endogenous contribution to the excretion of purines obtained for dairy cows (Gonzalez-Ronquillo et al., 2003).

The synthesis of microbial nitrogenous compounds in the rumen (micN g/day) was calculated in function of $\mathrm{AP}(\mathrm{mmol} /$ day $)$, by the equation: $\mathrm{micN}=\left(70^{*} \mathrm{AP}\right) /$ $\left(0.83 * 0.116^{*} 1000\right)$, in which 70 accounts for the content of $\mathrm{N}$ in the purines ( $\mathrm{mg} \mathrm{N} / \mathrm{mmol}$ ); 0.83 , the digestibility of microbial purines; and 0.116 , the $\mathrm{N}$-purine:total $\mathrm{N}$ ratio in the bacteria (Chen \& Gomes, 1992).

The balance of nitrogenous compounds (NB) was obtained by the difference between the total nitrogen ingested (Ning) and excreted in the feces ( $\mathrm{N}$-feces), in the urine (N-urine) and in the milk (N-milk). The determination of the total nitrogen in the feces and in the urine was done according to the technique described in Silva \& Queiroz (2002).

The dataset was subjected to tests of conformity of homogeneity of variance (Cochran) and normality (Lilliefors), confirming the normality and homoscedasticity of the data. They were subjected to analysis of variance utilizing the mixed model (PROCMIXED, Statistical Analysis System, 9.2):

$\mathrm{Y}_{\mathrm{ijkl}}=\mu+\mathrm{S}_{\mathrm{i}}+\mathrm{T}_{\mathrm{j}}+(\mathrm{P} / \mathrm{S})_{\mathrm{ik}}+(\mathrm{C} / \mathrm{S})_{\mathrm{il}}+\mathrm{S} \times \mathrm{T}_{\mathrm{ij}}+\mathrm{e}_{\mathrm{ijkl}}$,

In which $\mathrm{Y}_{\mathrm{ijk}}=$ observation in cow 1 , in period $\mathrm{k}$, subjected to treatment $\mathrm{j}$, in latin square $\mathrm{i} ; \mu=$ overall mean; $S_{i}=$ effect of latin square $i$, in which $i=1,2,3$; $\mathrm{T}_{\mathrm{j}}=$ effect of treatment $\mathrm{j}$, in which $\mathrm{j}=1,2,3,4 ;(\mathrm{P} / \mathrm{S})_{\mathrm{ik}}=$ effect of period $\mathrm{k}$, within latin square $\mathrm{i}$, in which $\mathrm{k}=1,2,3,4$; $(\mathrm{C} / \mathrm{S})_{\mathrm{il}}=$ effect of cow 1 , within latin square $\mathrm{i}$, in which $1=1,2,3,4 ; \mathrm{S} \times \mathrm{T}_{\mathrm{ij}}=$ effect of interaction between latin square $\mathrm{i}$ and treatment $\mathrm{j}$; e $\mathrm{e}_{\mathrm{ij \textrm {jl }}}=$ random effect, associated with each observation, assumption of NID $\left(0 ; \sigma^{2}\right)$. All the effects were considered fixed, except for $(\mathrm{C} / \mathrm{S})_{\mathrm{il}}$; and $\mathrm{e}_{\mathrm{ijk} \mathrm{k}}$, considered random.

The test of Williams (Williams, 1971) was applied, specifically for comparison of means of quantitative nature. Probability level of 0.05 was adopted for type I error. The results were presented as means of the minimum squares.

\section{Results and Discussion}

The substitution of SBM by CMT modified the composition of the nitrogenous compounds $(\mathrm{N})$ and of the carbohydrate fraction of the diet (Table 2). The fractions of non-protein N (NPN), neutral detergent insoluble N (NDIN) and acid detergent insoluble N (ADIN) increased in 54, 32 and $18 \%$ with the total replacement of SBM by CMT. The elevation of the NPN fraction occurred due to the greater inclusion of the mixture of urea and ammonium sulfate in the diet. In spite of the enlargement of the $\mathrm{N}$ fractions associated with the carbohydrates and lignin of the cell wall (NDIN and ADIN), which are considered of low availability to the rumen microorganisms and those of low intestinal digestibility (Van Soest, 1994; Detmann et al., 2006; Henriques et al., 2007), the greater increase of the NPN fraction enabled an increase of $11 \%$ in the content of RDP in the diet with the total replacement of SBM by CMT.

The NDF content increased $6 \%$, and that of NFC reduced $10 \%$ with the total replacement of SBM by CMT. Moreover, the contents of lignin and cutin increased in $11 \%$ and $142 \%$, which contributed to increase the acid detergent indigestible fraction in the diet in $41 \%$ with the total replacement of SBM by CMT. The majoritarian participation of cutin in the NDFap of CMT $(62 \%$ in the NDFap) was similar to the value observed by Oliveira et al. (2010b), of $63.82 \%$ of the NDFap, and indicates elevated presence of the hulls of the castor seed (Van Soest, 1994). Cutin is the main non-phenolic fraction of crude lignin, composed of polymers of esters of hydroxy long-chain fatty acids and alcohols, present in the epidermis of plant tissues, promoting superficial protection to them. Although it does not form bonds with carbohydrates, for being indigestible, it is a barrier to the entrance of rumen microorganisms, reducing the extent of digestion (Van Soest, 1994).

The presence of the two subunits of ricin and of other proteins soluble in buffer $\mathrm{pH} 3.8$ was verified in $\mathrm{CM}$, indicating that although the process of oil extraction with solvent is capable of destroying the toxin (Kim, 2011), it still presents residues, requiring procedures for detoxification. The effectiveness of the alkaline treatment can be evaluated by the difference in the intensity of the subunits of ricin (35 $\mathrm{kDa}$ and $29 \mathrm{kDa}$ ) in the polyacrylamide gel (SDSPAGE). In this sense, it could be verified that the alkaline treatment provoked complete denaturation of the ricin (Figure 1). According to the densitometric analysis, the content of ricin in the $\mathrm{CM}$ was reduced from $1,004.6$ to $73.9 \mathrm{mg} / \mathrm{kg} \mathrm{DM}$ of meal with the alkaline treatment, with detoxification effectiveness of $92.6 \%$, confirming the results verified by Oliveira et al. $(2007 ; 2010 \mathrm{a})$.

According to Oliveira et al. (2010a), with the alkaline treatment, the $\mathrm{pH}$ values (12.5) of $\mathrm{CM}$ surpass the isoelectric point value of ricin of 5.2 to 5.5 , making the net charge of protein negative, provoking electrostatic 
repulsion, breakage of hydrogen bonds which maintain the tridimensional structure and consequently, denaturation of the protein. Denaturation represents extreme alterations in the tridimensional structure of a protein which does not involve breakage of peptide bonds and is almost always linked to loss of function. In addition to loss of function, hydrophobic groups are exposed during denaturation, resulting in decrease in the solubility of protein in aqueous solutions. Thus, the disappearance of ricin subunits indicates absence of their solubility to buffer $\mathrm{pH} 3.8$ (optimal value of ricin extraction, according to Waller \& Negi (1958)), because of changes to the denatured state of the toxin when subjected to the alkaline treatment (Oliveira et al., 2010a).

Although the ricin intake increased $(\mathrm{P}<0.05)$ from the replacement of $0.33 \mathrm{~kg} / \mathrm{kg}$ of SBM by CMT (maximum value of $0.311 \mathrm{mg}$ ricin $/ \mathrm{kg}$ body weight), there was no effect $(\mathrm{P}>0.05)$ on the serum levels of the enzymes gamma glutamyl transpeptidase (GGT), alanine aminotransaminase (ALT) and aspartate aminotransaminase (AST) (Table 3). These results indicate absence of clinic effect of intoxication by ricin, for the serum levels of GGT, ALT and AST constitute markers of liver function which elevate at the occurrence of liver injury and are associated with the occurrence of intoxication by ricin in rats and sheep (Kumar et al., 2003; Aslani et al., 2007). Besides, the values of enzymes observed are within the standards established as normal for the species (Radostits et al., 2002). The main reason for the absence of intoxication in the animals is because of the alkaline treatment of $\mathrm{CM}$, which promoted ricin ingestion at levels below the level considered tolerable for ruminants of 2.37 (Oliveira et al., 2010b) and $3.06 \mathrm{mg} / \mathrm{kg}$ body weight (Diniz et al., 2010).

The DM intake was not affected $(\mathrm{P}>0.05)$ up to $0.33 \mathrm{~kg} / \mathrm{kg}$ replacement of SBM by $\mathrm{CMT}$, but reduced $(\mathrm{P}<0.05)$ from $0.67 \mathrm{~kg} / \mathrm{kg}$ replacement (Table 4). The decrease in DM intake may be associated with the greater content of NDF and NDF intake $(\mathrm{P}<0.05)$, and, especially, with the greater indigestible fraction of NDF and CMT in relation to SBM, due to the higher content of cutin of the CMT (Table 1).

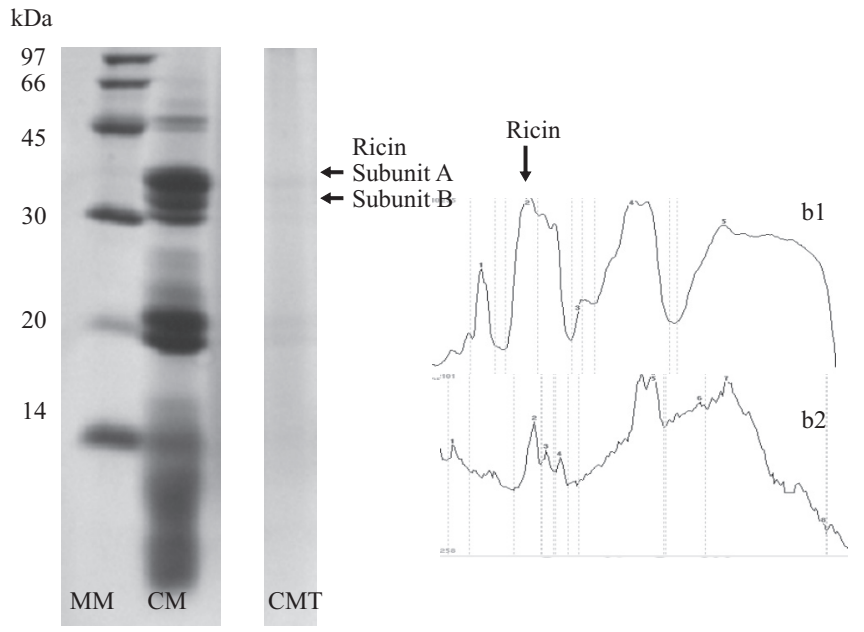

MM - molecular weight marker between 14 and $97 \mathrm{kDa}$. Densitometric analysis of the gel (SDS-PAGE) of the CM (b.1) and of CMT (b.2) [B].

The ordinate axis represents the unit of relative density, and the abscissa axis shows the protein fractions expressed in unit of relative molecular mass (from the highest to the lowest value). The ricin area is indicated by the arrow.

Figure 1 - Polyacrylamide gel (SDS-PAGE) for the evaluation of the effectiveness of the treatment with castor seed meal $(\mathrm{CM})$ with $60 \mathrm{~g} \mathrm{CaO} / \mathrm{kg}$ natural matter (CMT) in the disappearance of ricin (subunit A with $35 \mathrm{kDa}$ and subunit B with $29 \mathrm{kDa}$ ) [A].

Basically, the enlargement of the indigestible fraction of NDF enhanced the effect of rumen fill, once the disappearance of this fraction is affected only by the passage, whereas the disappearance of the potentially digestible fraction of the NDF (NDF-iNDF) is affected by passage and digestion (Allen \& Mertens, 1988; Oliveira et al., 2011).

Crude protein and NFC intake also reduced $(\mathrm{P}<0.05)$ from $0.67 \mathrm{~kg} / \mathrm{kg}$ of replacement (Table 4), due to the decrease in DM and reduction in the dietary content (only for NFC). The consumption of rumen-degradable protein (RDP) was not affected $(\mathrm{P}>0.05)$, but the intake of rumen-undegradable protein (RUP) reduced from $0.67 \mathrm{~kg} / \mathrm{kg}$ of replacement (Table 4). The absence of effect on RDP intake is because of the increase in the RDP in the diet (Table 2), which compensated the reduction in DM intake. As previously discussed, although the rumen degradability of CMT is

Table 3 - Daily intake of ricin and plasma levels of gamma glutamyl transpeptidase, alanine aminotransaminase and aspartate aminotransaminase in dairy cows receiving diets with different levels of replacement of soybean meal by castor seed meal treated with $60 \mathrm{~g}$ calcium oxide $/ \mathrm{kg}$

\begin{tabular}{|c|c|c|c|c|c|}
\hline \multirow{2}{*}{ Item } & \multicolumn{4}{|c|}{ Replacement of soybean meal by castor seed meal (kg/kg) } & \multirow{2}{*}{ CV $(\%)$} \\
\hline & 0.00 & 0.33 & 0.67 & 1.00 & \\
\hline Ricin, mg/day & 0.00 & $63.25 *$ & 114.40 & 168.87 & 21.67 \\
\hline Ricin, mg/body weight/day & 0.00 & $0.115^{*}$ & 0.209 & 0.311 & 19.58 \\
\hline Gamma glutamyl transpeptidase, UI/L & 23.75 & 21.50 & 24.22 & 24.09 & 14.83 \\
\hline Alanine aminotransaminase, $\mathrm{UI} / \mathrm{L}$ & 24.81 & 25.44 & 25.88 & 27.31 & 13.29 \\
\hline Aspartate aminotransaminase, UI/L & 68.53 & 65.44 & 68.19 & 71.28 & 17.77 \\
\hline
\end{tabular}

Means followed by $\left(^{*}\right)$ indicate the level of inclusion from which there is difference in relation to the control diet (level zero) by the test of William (P $\left.<0.05\right)$.

$\mathrm{CV}$ - coefficient of variation. 
lower than that of SBM (Oliveira et al., 2010b), the increase in the RDP content in the diet with replacement of SBM by CMT happened because of the increase in the inclusion of the mixture of urea and ammonium sulfate (Table 2).

Although the digestibility of all the components of the diet (DM, OM, CP, NDFap and NFC), except for EE and the TDN content were reduced $(\mathrm{P}<0.05)$ from $0.33 \mathrm{~kg} / \mathrm{kg}$ replacement of SBM by CMT, the intake of DM, OM, CP, NDFap, digestible NFC and TDN were not affected $(\mathrm{P}>0.05)$ up to this level (Table 5).

The decrease in $\mathrm{CP}$ digestibility was probably due to increase in the fractions of NDIN and ADIN of the diet, as well as due to decrease in CP intake, which increase the participation of the fecal metabolic fraction. The reduction in the digestibility of NDFap occurred due to the enlargement of the lignin content and especially cutin, with replacement of SBM by CMT (Oliveira et al., 2010b). The decrease in the NFC digestibility, in turn, happened due to the decrease in NFC intake, which increased the participation of the fecal metabolic fraction (Van Soest., 1994).

The urinary excretion of purine derivatives, the synthesis of microbial $\mathrm{N}$ and the utilization efficiency of the RDP for the synthesis of microbial $\mathrm{N}$ in the rumen were not affected $(\mathrm{P}>0.05)$ up to $0.67 \mathrm{~kg} / \mathrm{kg}$ of replacement, but reduced $(\mathrm{P}<0.05)$ with the total replacement of SBM by CMT (Table 6).

The reduction in the synthesis of microbial $\mathrm{N}$ as well as in the utilization efficiency of RDP occurred because of the lower availability of digestible carbohydrates (NFC and NDF) with the replacement of SBM by CMT, which are essential to make energy and carbon skeleton available for the microbial growth (NRC, 2001; Bach et al., 2005).

Table 4 - Daily intake of lactating dairy cows fed diets containing different levels of replacement of soybean meal by castor seed meal treated with $60 \mathrm{~g}$ calcium oxide $/ \mathrm{kg}$

\begin{tabular}{|c|c|c|c|c|c|}
\hline \multirow{2}{*}{ Item } & \multicolumn{4}{|c|}{ Replacement of soybean meal by castor seed meal $(\mathrm{kg} / \mathrm{kg})$} & \multirow{2}{*}{$\mathrm{CV}(\%)$} \\
\hline & 0.00 & 0.33 & 0.67 & 1.00 & \\
\hline Total dry matter (kg/day) & 16.41 & 17.20 & $15.73 *$ & 15.20 & 6.32 \\
\hline Organic matter (kg/day) & 15.27 & 15.88 & 15.40 & $13.79 *$ & 6.27 \\
\hline Ether extract (kg/day) & 0.40 & 0.42 & 0.41 & 0.40 & 5.77 \\
\hline Crude protein (kg/day) & 2.67 & 2.75 & $2.47^{*}$ & 2.43 & 7.77 \\
\hline Rumen-degradable protein $(\mathrm{kg} /$ day $)$ & 1.59 & 1.71 & 1.61 & 1.61 & 7.11 \\
\hline Rumen-undegradable protein (kg/day) & 1.08 & 1.04 & $0.86^{*}$ & 0.82 & 11.33 \\
\hline NDFap (kg/day) & 6.40 & $7.01 *$ & 6.66 & 6.52 & 6.90 \\
\hline Non-fibrous carbohydrates (kg/day) & 5.79 & 5.70 & $4.87^{*}$ & 4.45 & 7.21 \\
\hline Dry matter (g/kg body weight) & 30.3 & 31.7 & $29.1 *$ & 28.3 & 6.36 \\
\hline NDFap (g/kg body weight) & 11.9 & $12.9 *$ & 12.3 & 12.2 & 7.18 \\
\hline
\end{tabular}

Means followed by $(*)$ indicate the level of inclusion from which there is difference in relation to the control diet (level zero) by the test of William (P $<0.05)$.

NDFap - neutral detergent fiber corrected for ash and protein; CV - coefficient of variation.

Table 5 - Total digestibility of the diet components, total digestible nutrients of the diet and on the daily intake of digestible components of lactating dairy cows fed diets containing different levels of replacement of soybean meal by castor seed meal treated with $60 \mathrm{~g}$ calcium oxide $/ \mathrm{kg}$

\begin{tabular}{|c|c|c|c|c|c|}
\hline \multirow{2}{*}{ Item } & \multicolumn{4}{|c|}{ Replacement of soybean meal by castor seed meal (kg/kg DM) } & \multirow{2}{*}{$\mathrm{CV}(\%)$} \\
\hline & 0.00 & 0.33 & 0.67 & 1.00 & \\
\hline \multicolumn{6}{|l|}{ Digestibility, $\mathrm{g} / \mathrm{g}$} \\
\hline Dry matter & 0.673 & $0.645^{*}$ & 0.623 & 0.592 & 5.15 \\
\hline Organic matter & 0.691 & $0.665 *$ & 0.641 & 0.609 & 4.78 \\
\hline Ether extract & 0.873 & $0.895 *$ & 0.942 & 0.938 & 6.46 \\
\hline Crude protein & 0.711 & $0.683 *$ & 0.689 & 0.671 & 5.57 \\
\hline NDF corrected for ash and protein (NDFap) & 0.576 & $0.548 *$ & 0.517 & 0.475 & 8.54 \\
\hline Non-fibrous carbohydrates & 0.798 & $0.780 *$ & 0.756 & 0.736 & 2.87 \\
\hline Total digestible nutrients, $\mathrm{g} / \mathrm{g} \mathrm{DM}$ & 0.671 & $0.643 *$ & 0.619 & 0.584 & 4.74 \\
\hline \multicolumn{6}{|l|}{ Intake, $\mathrm{kg}$} \\
\hline Digestible dry matter & 11.04 & 11.09 & $9.80 *$ & 9.00 & 7.15 \\
\hline Digestible organic matter & 10.56 & 10.56 & $9.88 *$ & 8.40 & 6.81 \\
\hline Digestible ether extract & 0.35 & 0.38 & 0.39 & 0.38 & 10.50 \\
\hline Digestible crude protein & 1.90 & 1.88 & $1.70^{*}$ & 1.63 & 9.96 \\
\hline Digestible NDFap & 3.69 & 3.84 & $3.44^{*}$ & 3.09 & 9.14 \\
\hline Digestible non-fibrous carbohydrates & 4.61 & 4.44 & $3.70 *$ & 3.27 & 7.41 \\
\hline Total digestible nutrients & 10.99 & 11.01 & $9.71 *$ & 8.84 & 6.78 \\
\hline
\end{tabular}

Means followed by $(*)$ indicate the level of inclusion from which there is difference in relation to the control diet (level zero) by the test of William (P $<0.05)$.

$\mathrm{DM}$ - dry matter; CV - coefficient of variation. 
It was verified that the fixed value of utilization efficiency of RDP for the synthesis of rumen microbial $\mathrm{N}$ utilized by the NRC (2001) and suggested by Bach et al. (2005), of 0.85 (disregarding the fraction of endogenous $\mathrm{N})$, was not within $(\mathrm{P}<0.05)$ the confidence interval $(\mathrm{CI})$ obtained from the observed values of CI $(\mu)_{95 \%}=0.77 \pm 0.05$. On the other hand, considering only the diets with 0 and $0.33 \mathrm{~kg} / \mathrm{kg}$ of replacement of SBM by CMT, the mean value was 0.85 , similar to the adopted by the NRC (2001), demonstrating that for diets with adequate supply of digestible carbohydrates, the fixed value utilized by the NRC (2001) seems to be adequate.

The utilization efficiency of energy available for the synthesis of rumen microbial $\mathrm{N}$ was not affected $(\mathrm{P}>0.05)$ by the replacement of SBM by CMT (Table 6). Since the availability of rumen N (RDP intake) was kept constant, the absence of effect on the utilization efficiency of energy was expected, because, as demonstrated by the NRC (2001), the utilization efficiency of the energy available for the rumen microbial growth is not very affected by the intake of available energy, when the availability of rumen $\mathrm{N}$ is kept constant. It is worth stressing that the fixed values of 130 and $120 \mathrm{~g}$ of microbial $\mathrm{CP} / \mathrm{kg}$ of TDN ingested suggested by the NRC (2001) and by Valadares Filho et al. (2006) for tropical conditions are within $(\mathrm{P}<0.05)$ the confidence interval (CI) obtained from the observed values of CI $(\mu)_{95 \%}=$ $126.39 \pm 7.46$, which indicates that both values can be utilized for prediction of the synthesis of rumen microbial CP.

Milk yield, MY corrected for $35 \mathrm{~g}$ fat $/ \mathrm{kg}$ of milk, contents of $\mathrm{CP}$ and nonfat solids, as well as the daily production of lactose, $\mathrm{CP}$, fat, total solids and nonfat solids in the milk were not affected $(\mathrm{P}>0.05)$ up to $0.33 \mathrm{~kg} / \mathrm{kg}$ of replacement, but decreased $(\mathrm{P}<0.05)$ from the replacement of $0.67 \mathrm{~kg} / \mathrm{kg}$ of SBM by CMT (Table 7). However, feeding efficiency was not affected $(\mathrm{P}>0.05)$, since the reduction of MYC was followed by decrease in DM intake. The variation in body weight reduced $(\mathrm{P}<0.05)$ from $0.67 \mathrm{~kg} / \mathrm{kg}$ of replacement, presenting mean values of $0.65,0.67,0.20$

Table 6 - Effect of the level of replacement of soybean meal by castor seed meal treated with $60 \mathrm{~g}$ calcium oxide/kg on the daily excretion of purine derivatives, synthesis and efficiency of the synthesis of microbial nitrogenous compounds $(\mathrm{N})$ in the rumen of lactating dairy cows

\begin{tabular}{|c|c|c|c|c|c|}
\hline \multirow{2}{*}{ Item } & \multicolumn{4}{|c|}{ Replacement of soybean meal by castor seed meal $(\mathrm{kg} / \mathrm{kg})$} & \multirow{2}{*}{$\mathrm{CV}(\%)$} \\
\hline & 0.00 & 0.33 & 0.67 & 1.00 & \\
\hline \multicolumn{6}{|l|}{ Urinary excretion } \\
\hline Allantoin, $\mathrm{mmol} / \mathrm{d}$ & 286.75 & 286.60 & 265.30 & $229.39 *$ & 17.09 \\
\hline Uric acid, mmol/d & 30.70 & 31.05 & $27.46^{*}$ & 24.10 & 16.07 \\
\hline Allantoin in the milk, $\mathrm{mmol} / \mathrm{d}$ & 2.14 & 2.12 & 1.64 & 2.36 & 40.42 \\
\hline Total excreted purine derivatives, $\mathrm{mmol} / \mathrm{d}$ & 319.59 & 319.67 & 294.40 & $255.85^{*}$ & 16.06 \\
\hline Absorbed purines, $\mathrm{mmol} / \mathrm{d}$ & 308.43 & 308.25 & 278.98 & $233.98^{*}$ & 19.93 \\
\hline $\mathrm{g} \mathrm{micCP} / \mathrm{kg}$ TDN intake & 127.53 & 127.22 & 130.56 & 120.28 & 17.39 \\
\hline $\mathrm{g}$ micCP/g RDP intake & 0.881 & 0.819 & $0.792 *$ & 0.656 & 18.06 \\
\hline
\end{tabular}

Means followed by $(*)$ indicate the level of inclusion from which there is difference in relation to the control diet (level zero) by the test of William $(\mathrm{P}<0.05)$.

$\mathrm{CV}$ - coefficient of variation.

Table 7 - Production and composition of the milk from dairy cows fed diets containing different levels of replacement of soybean meal by castor seed meal treated with $60 \mathrm{~g}$ calcium oxide/kg

\begin{tabular}{|c|c|c|c|c|c|}
\hline \multirow{2}{*}{ Item } & \multicolumn{4}{|c|}{ Replacement of soybean meal by castor seed meal (kg/kg) } & \multirow{2}{*}{$\mathrm{CV}(\%)$} \\
\hline & 0.00 & 0.33 & 0.67 & 1.00 & \\
\hline Milk, kg/d & 20.82 & 21.22 & $19.15^{*}$ & 18.81 & 7.60 \\
\hline Milk with $3.5 \%$ fat (MYC), $\mathrm{kg} / \mathrm{d}$ & 21.11 & 21.71 & $19.28 *$ & 18.78 & 7.73 \\
\hline Lactose, $\mathrm{g} / \mathrm{kg}$ & 45.0 & 45.6 & 45.6 & 45.1 & 1.71 \\
\hline Crude protein, $\mathrm{g} / \mathrm{kg}$ & 31.4 & 30.9 & $29.6^{*}$ & 28.8 & 2.71 \\
\hline Fat, $\mathrm{g} / \mathrm{kg}$ & 37.1 & 37.0 & 36.1 & 35.8 & 6.70 \\
\hline Protein:fat & 0.85 & 0.84 & 0.82 & $0.80 *$ & 7.30 \\
\hline Total solids, g/kg & 12.41 & 12.42 & 12.10 & 11.94 & 2.73 \\
\hline Nonfat total solids, $\mathrm{g} / \mathrm{kg}$ & 8.66 & 8.65 & $8.50 *$ & 8.36 & 1.38 \\
\hline Lactose, $\mathrm{kg} / \mathrm{d}$ & 0.94 & 0.97 & $0.87 *$ & 0.85 & 7.91 \\
\hline Protein, kg/d & 0.65 & 0.66 & $0.57 *$ & 0.54 & 7.61 \\
\hline Fat, kg/d & 0.77 & 0.79 & $0.69 *$ & 0.67 & 9.31 \\
\hline Total solids, $\mathrm{kg} / \mathrm{d}$ & 2.58 & 2.64 & $2.32 *$ & 2.25 & 7.31 \\
\hline Nonfat total solids, $\mathrm{kg} / \mathrm{d}$ & 1.80 & 1.84 & $1.63 *$ & 1.57 & 7.49 \\
\hline MYC/DM intake & 0.79 & 0.81 & 0.82 & 0.81 & 9.08 \\
\hline
\end{tabular}

Means followed by $(*)$ indicate the level of inclusion from which there is difference in relation to the control diet (level zero) by the test of William ( $\mathrm{P}<0.05)$.

$\mathrm{CV}$ - coefficient of variation. 
and $-0.23 \mathrm{~kg} / \mathrm{day}$ for the levels $0 ; 0.33 ; 0.67$ and $1.0 \mathrm{~kg} / \mathrm{kg}$ of replacement of SBM by CMT.

The reduction in MY occurred mostly due to the decrease in the production of lactose, which represents the main osmotic component of milk. The decrease in the production of lactose was a result of the lower intake of digestible carbohydrates (NFC and NDF), which reduced the flow of blood glucose in the mammary gland. Furthermore, reduction in the synthesis of rumen microbial $\mathrm{N}$ might also have contributed to decrease in the production of lactose, because of the diminution in the flow of amino acids to the mammary gland. The protein alpha-lactalbumin, synthesized in the mammary gland from free amino acids absorbed in the blood circulation, plays an essential role in the catalytic action of the enzyme complex lactose synthase (Fonseca, 1995). In this sense, decrease in the flow of amino acids of microbial origin possibly reduced the alpha-lactalbumin synthesis in the mammary gland, compromising the synthesis of lactose as well (Gennadij et al., 2000).

The decrease in the content and production of $\mathrm{CP}$ of the milk was caused by the decrease in the synthesis of rumen microbial N, which led to reduction of the flow of amino acids towards the mammary gland. Besides, the decrease in the flow of glucose in the mammary gland from the decrease in the digestible carbohydrate intake might also have contributed to the depression in the $\mathrm{CP}$ content of the milk, since the secreting cells of the mammary gland utilize principally the catabolism of glucose to provide the energy necessary for the processes of capture of amino acids, synthesis and transport of milk proteins (Fonseca, 1995; Mackle et al., 2000).

The reduction in the production of fat of the milk might have occurred as a result of the decrease in the availability of acetate and glucose necessary for the synthesis of triglycerides in the mammary gland. The synthesis of triglycerides in the mammary gland depends on the blood supply of long-chain fatty acids, on the de novo synthesis of short- and medium-chain fatty acids (SMCFA) and on the concentration of reduction cofactors $\left(\mathrm{NADPH}_{2}\right)$, necessary for the supply of electrons and for the enzyme complex in charge of the MCFA and of glycerol. The acetate and $B-\mathrm{OH}$-butyrate originated from the ruminal degradation of carbohydrates, notably those of the cell wall, are the main sources of carbon for the de novo synthesis of SMCFA in the mammary gland in ruminants (Grummer, 1991). Thus, the decrease in digestible NDFap intake from $0.67 \mathrm{~kg} / \mathrm{kg}$ of replacement of SBM by CMT reduced the availability of carbon sources for the de novo synthesis of SMCFA.

At the same time, the diminution in digestible NDF intake might also have affected the synthesis of fat in the mammary gland, through reduction of the flow of glucose in the mammary gland. In in vitro studies, utilizing the adipose tissue of cattle and sheep at different ages and physiological stages, it was demonstrated that the addition of glucose to the acetate marked with $\mathrm{C}^{14}$ increased the synthesis of fatty acids at more than four times in relation to the treatment without glucose (Ingle et al., 1972). Although glucose represents minimal contribution to the supply of carbon to the de novo synthesis of MCFA in the mammary gland of ruminants, it plays a fundamental role in the supply of reduction cofactors and glycerol (Ingle et al., 1972; Van Soest, 1994; Grummer, 2001).

The concentration of plasma urea nitrogen (PUN) increased $(\mathrm{P}<0.05)$ from $0.33 \mathrm{~kg} / \mathrm{kg}$ of replacement (Table 8) due to the enlargement of the NPN fraction in

Table 8 - Concentration of plasma urea nitrogen and milk urea nitrogen, urinary excretion of nitrogenous compounds ( $\mathrm{N})$, $\mathrm{N}$ balance and utilization efficiency of $\mathrm{N}$ in lactating dairy cows fed diets containing different levels of replacement of soybean meal (SBM) by castor seed meal treated with $60 \mathrm{~g}$ calcium oxide $/ \mathrm{kg}$

\begin{tabular}{|c|c|c|c|c|c|}
\hline \multirow{2}{*}{ Item } & \multicolumn{4}{|c|}{ Replacement of soybean meal by castor seed meal (kg/kg) } & \multirow{2}{*}{ CV $(\%)$} \\
\hline & 0.00 & 0.33 & 0.67 & 1.00 & \\
\hline PUN, mg/dL & 13.15 & $16.38 *$ & 15.37 & 17.40 & 17.24 \\
\hline \multicolumn{6}{|l|}{ Urinary excretion } \\
\hline $\mathrm{N}, \mathrm{g} / \mathrm{d}$ & 129.20 & 131.46 & 123.07 & 126.02 & 14.28 \\
\hline $\mathrm{N}$-urea, mg/d & 91.68 & 92.84 & 89.24 & 100.48 & 15.95 \\
\hline $\mathrm{N}$-urea/N, g/g N & 0709 & 0.706 & 0.725 & $0.797 *$ & 8.63 \\
\hline $\mathrm{N}$ ingested, $\mathrm{g} / \mathrm{d}$ & 427.20 & 440.0 & $395.20 *$ & 388.80 & 7.55 \\
\hline $\mathrm{N}$ in the milk, $\mathrm{g} / \mathrm{d}$ & 104.60 & 104.91 & $90.69 *$ & 86.68 & 7.56 \\
\hline $\mathrm{N}$ in the feces, $\mathrm{g} / \mathrm{d}$ & 121.60 & 136.00 & 121.60 & 129.60 & 12.55 \\
\hline $\mathrm{N}$ balance, $\mathrm{g} / \mathrm{d}$ & 71.80 & 67.63 & 59.84 & $46.50 *$ & 43.35 \\
\hline $\mathrm{N}$ in the milk, $\mathrm{g} / \mathrm{g} \mathrm{N}$ ingested & 244.8 & 237.2 & $229.5^{*}$ & 222.9 & 7.56 \\
\hline $\mathrm{N}$ in the feces, $\mathrm{g} / \mathrm{g} \mathrm{N}$ ingested & 284.6 & 309.1 & 307.7 & $333.3 *$ & 12.54 \\
\hline $\mathrm{N}$ in the urine, $\mathrm{g} / \mathrm{g} \mathrm{N}$ ingested & 302.4 & 298.8 & 311.4 & 324.1 & 14.28 \\
\hline $\mathrm{N}$ balance, $\mathrm{g} / \mathrm{g} \mathrm{N}$ ingested & 168.1 & 153.7 & 151.4 & 119.6 & 39.69 \\
\hline
\end{tabular}

Means followed by $\left(^{*}\right)$ indicate the level of inclusion from which there is difference in relation to the control diet (level zero) by the test of William (P $\left.<0.05\right)$. $\mathrm{CV}$ - coefficient of variation. 
the diet (Table 2). However, the PUN values are within the range considered adequate for the balance of energy and protein, from 10 to $17 \mathrm{mg} / \mathrm{dL}$ (Broderick, 1995; Moore \& Varga, 1996; Jonker et al., 1998; Ferguson, 2010). The urinary excretion of urea $\mathrm{N}$ was not affected $(\mathrm{P}>0.05)$ up to $0.67 \mathrm{~kg} / \mathrm{kg}$ of replacement, but increased $(\mathrm{P}<0.05)$ with the total replacement of SBM by CMT (Table 8), due to the increase of the NPN in the diet (Table 2).

The utilization efficiency of the $\mathrm{N}$ ingested for the production of $\mathrm{N}$ in the milk was not affected $(\mathrm{P}>0.05)$ up to $0.33 \mathrm{~kg} / \mathrm{kg}$ of replacement, but reduced $(\mathrm{P}<0.05)$ from the replacement of $0.67 \mathrm{~kg} / \mathrm{kg} \mathrm{SBM}$ by CMT (Table 8 ), due to the lower efficiency of capture of the $\mathrm{N}$ available in the rumen (RDP) for the synthesis of microbial N (Table 6). However, it must be emphasized that there was no negative mean value for NB at any of the levels of replacement of SBM by CMT, indicating that the $\mathrm{N}$ intake met the $\mathrm{N}$ requirement of cows (Table 8).

\section{Conclusions}

Castor seed meal treated with $60 \mathrm{~g}$ calcium oxide/kg (natural matter basis) can replace up to one third of the soybean meal in diets (inclusion of $50 \mathrm{~g} / \mathrm{kg} \mathrm{DM}$ ) for dairy cows with production of $20 \mathrm{~kg}$ milk/day, without affecting the consumption of the digestible components of the diet, animal productive performance or the utilization efficiency of the nitrogenous compounds of the diet.

\section{References}

ALLEN, M.S.; MERTENS, D.R. Evaluationg constraints on fiber digestion by rumen microbes. Journal of Nutrition, v.118, p.261-270, 1988

ARMIÉN, A.G.; D'ANGELIS, F.H.F.; TOKARNIA, C.H. Intoxicação experimental pelas sementes de Ricinus communis (Euphorbiaceae) em ovinos. Brazilian Journal of Veterinary Research, v.16, p.99-106, 1996.

ASLANI, M.R.; MALEKI, M.; MOHRI, M. et al. Castor bean (Ricinus communis) toxicosis in a sheep flock. Toxicon, v.49, p.400-406, 2007.

BACH, A.; CALSAMIGLIA, S.; STERN, M.D. Nitrogen metabolism in the rumen. Journal of Dairy Science, v.88, Suppl. E., p.9-21, 2005.

BRADFORD, M.M. A rapid sensitive method for quantitation of microgram quantities of protein utilizing the principle of protein dye binding. Analytical Biochemistry, v.72, p.248-254, 1976.

BORCHERS, R. Castor bean meal. Part 1: Destruction of the toxic factor. Poulty Science, v.28, p.568-570, 1949.

BRODERICK, G.A. Use of milk urea as an indicator of nitrogen utilization in lactating dairy cows. Madison: USDA. Agriculture Research Service; US Dairy Forage Research Center, 1995. 122p. (Research Summaries).

CASALI, A.O. Procedimentos metodológicos in situ na avaliação de compostos indigestíveis em alimentos e fezes de bovinos. 2006. 47f. Dissertação (Mestrado em Zootecnia) - Universidade Federal de Viçosas, Viçosa, MG.
CHEN, X.B.; GOMES, M.J. Estimation of microbial protein supply to sheep and cattle based on urinary excretion of purine derivatives - an overview of technical details. International Feed Research Unit. Aberdeen: Rowett Research Institute, 1992. 21p. (Occasional publication).

CHIZZOTTI, M.L.; VALADARES FILHO, S.C.; VALADARES, R.F.D. et al. Determination of creatinine excretion and evaluation of spot urine sampling in Holstein cattle. Livestock Science, v.113, p.218-225, 2008

DETMANN, E.; PAULINO, M.F.; COELHO DA SILVA, J.F. et al. Digestibilidade dos compostos nitrogenados insolúveis em detergente ácido em bovinos manejados em pastagens de capim braquiária. Revista Brasileira de Zootecnia, v.35, p.1463-1468, 2006.

DINIZ, L.L.; VALADARES FILHO, S.C.; CAMPOS, J.M.S. et al. Effects of castor meal on the growth performance and carcass characteristics of beef cattle. Asian-Australia Journal of Animal Science, v.23, p.1308-1318, 2010.

ENDO, Y.; TSURUGI, K. The RNA N-glycosidase activity of Ricin A-chain. The Journal of Biological Chemistry, v.263, p.8735-8739, 1988.

FERGUSON, J.D. Milk urea nitrogen. Center for Animal Health and Productivity, 2010, Kennet Square. Available at: $<$ http://cahpwww. vet.upenn.edu/mun/mun_info.html $>$ Accessed on: Jan. 10, 2005.

FONSECA, F.A. Fisiologia da lactação. Viçosa, MG: UFV/Centro de Ciências Agrárias/Departamento de Zootecnia. 1995. 137p.

GARDNER JR., H.K.; D'AQUIN, E.L.; KOULTUN, S.P. et al. Detoxification and deallergenization of castor beans. The Journal of the American Oil Chemists Society, v.37, p.142-148, 1960.

GENNADIJ, C.C.; DANFAER, A.; CANT, J.P. Simulation analysis of substrate utilization in the mammary gland of lactating cows. Journal of Dairy Research, p.171-188, 2000.

GONZÁLEZ-RONQUILLO, M.; BALCELLS, J.; GUADA, J.A. et al. Purine derivative excretion in dairy cows: Endogenous excretion and the effect of exogenous nucleic acid supply. Journal of Dairy Science, v.86, p.1282-1291, 2003.

GRUMMER, R.R. Effect of feed on the composition of milk fat. Journal of Dairy Science, v.74, p.3244-3257, 1991.

HALL, M.B. Calculation of non-structural carbohydrate content of feeds that contain non-protein nitrogen. Gainesville: University of Florida, 2000. P.A-25 (Bulletin 339).

HENRIQUES, L.T.; DETMANN, E.; QUEIROZ, A.C. et al. Frações dos compostos nitrogenados associados à parede celular em forragens tropicais. Arquivo Brasileiro de Medicina Veterinária e Zootecnia, v.59, p.258-263, 2007.

INTERNATIONAL DAIRY FEDERATION - IDF. Whole milk. Determination of milkfat, protein and lactose content Guide for the operation of mid-infra-red instuments. Bruxelas: 1996. 12p. (IDF Standard 141 B).

INGLE，D.L.; BAUMAN, D.E.; GARRIGUS, U.S. Lipogenesis in the ruminant: in vitro study of tissue sites, carbon source and reducing equivalent generation for fatty acid synthesis. Journal of Nutrition, p.609-616, 1972.

JONKER, J.S.; KOHN, R.A.; ERDMAM, R.A. Using milk urea nitrogen to predict nitrogen excretion and utilization efficiency in lactating dairy cows. Journal of Dairy Science, v.81, p.2681-2692, 1998.

KIM, B.K. Effects of oil milling steps on residual toxin and antigen activities of castor bean. Food Science and Biotechnology, v.10, p.305-310, 2001.

KODRAS, R.; WHITEHAIR, C.K.; MACVICAR, R. Studies on the detoxification of castor seed pomace. Journal of the American Oil Chemistry Society, v.26, p.641-644, 1949.

KUMAR, O.; SUGENDRAN, K.; VIJAYARAGHAVAN, R. Oxidative stress associated hepatic and renal toxicity induced by ricin in mice. Toxicon, v.41, p.333-338, 2003.

LAEMMLI, U.K. Cleavage of structural proteins during the assembly of head of bacteriophage T4. Nature, v.227, p.680-685, 1970.

LICITRA, G.; HERNANDEZ, T.M.; VAN SOEST, P.J. Standardization of procedures for nitrogen fractionation of ruminant feeds. Animal Feed Science and Technology, v.57, p.347-358, 1996. 
MACKLE, T.R.; DWYER, D.A.; INGVARTSEN, K.L. Effects of insulin and postruminal supply of protein on use of amino acids by the mammary gland for milk protein synthesis. Journal of Dairy Science, v.83, p.93-105, 2000.

MATOS, L.L. Substituição do farelo de algodão pelo farelo de mamona destoxicado na alimentação suplementar de vacas em lactação. 1976. 39f. Dissertação (Mestrado em Zootecnia) Universidade Federal de Viçosa, Viçosa, MG.

MERTENS, D.R. Gravimetric determination of amylase-treated neutral detergent fiber in feeds with refluxing in beaker or crucibles: collaborative study. Journal of AOAC International, v.85, p.1217-1240, 2002.

MOORE, D.A.; VARGA, G. BUN and MUN: Urea nitrogen testing in dairy cattle. Compendium Continuing Education Veterinary, v.18, p.712-721, 1996.

NATIONAL RESEARCH COUNCIL - NRC. Nutrient requirements of dairy cattle. 7.ed. Washington, DC: National Academy Press, 2001.381p.

OLIVEIRA, A.S. Co-produtos da extração de óleo de sementes de mamona e de girassol na alimentação de ruminantes. 2008. 166f. Tese (Doutorado em Zootecnia) - Universidade Federal de Viçosa, Viçosa, MG.

OLIVEIRA, A.S.; OLIVEIRA, M.R.C.; CAMPOS, J.M.S. et al. In vitro ruminal degradation of ricin and its effect on microbial growth. Animal Feed Science and Technology, v.157, p.41-54, 2010a.

OLIVEIRA, A.S.; CAMPOS, J.M.S.; OLIVEIRA, M.R.C. et al. Nutrient digestibility, nitrogen metabolism and hepatic function of sheep fed diets containing solvent or expeller castorseed meal treated with calcium hydroxide. Animal Feed Science and Technology, v.158, p.15-28, 2010b.

OLIVEIRA, A.S.; DETMANN, E.; CAMPOS, J.M.S. et al. Metaanalysis of the impact of neutral detergent fiber on intake, digestibility and performance of lactating dairy cows. Revista Brasileira de Zootecnia, v.40, p.1587-1595, 2011.

OLIVEIRA, A.S.; OLIVEIRA, M.R.C.; CAMPOS, J.M.S. et al. Eficácia de diferentes métodos de destoxificação da ricina no farelo de mamona. In: CONGRESSO DA REDE BRASILEIRA DE TECNOLOGIA E PRODUÇÃO DE BIODIESEL, 2., 2007, Brasília. Anais... Brasília, 2007. p.1-6.
OLSNES, S.; REFSNES, K.; PIHL, A. Mechanism of action of the toxic lectins abrin and ricin. Nature, v.249, p.627-631, 1974.

RADOSTITIS, O.M.; GAY, C.C.; BLOOD, D.C. et al. Clínica veterinária: Um tratado de doenças dos bovinos, ovinos, suínos, caprinos e eqüinos. 9.ed. Rio de Janeiro: Editora Guanabara Koogan, 2002. 1737p.

ROBB, J.G.; LABEN, R.C.; WALKER JR., H.G. Castor meal in dairy rations. Journal of Dairy Science, v.47, p.443-450, 1974.

SILVA, D.J.; QUEIROZ, A.C. Análise de alimentos: métodos químicos e biológicos. 3.ed. Viçosa, MG: UFV, 2002. 235p.

SKLAN, D.; ASHKENAZI, R.; BRAUN, A. et al. Fatty acids, calcium soaps of fatty acids and cottonseeds fed to high yielding cows. Journal of Dairy Science, v.75, p.2463-2472, 1992.

VALADARES FILHO, S.C.; PAULINO, P.V.R.; MAGALHÃES, K.A. Exigências nutricionais de zebuínos e tabelas de composição de alimentos BR-CORTE. 1.ed. Viçosa, MG: UFV, DZO, 2006. $142 \mathrm{p}$.

VALENTE, T.N.P. Utilização de tecidos na avaliação de compostos fibrosos e na degradação ruminal in situ de alimentos para ruminantes. 2010. 90f. Tese (Doutorado em Zootecnia) Universidade Federal de Viçosas, Viçosa, MG.

VAN SOEST, P.J. Nutritional ecology of the ruminants. 2.ed. Ithaca: Cornell University, 1994. 476p.

VERBIC, J.; CHEN, X.B.; MACLEOD, N.A. et al. Excretion of purine derivatives by ruminants. Effect of microbial nucleic acid infusion on purine derivative excretion by steers. Journal Agriculture Science, v.114, p.243-248, 1990.

WALLER, G.R.; NEGI, S.S. Isolation of ricin, ricinine, and the allergenic fraction from castor seed pomace from two different sources. Journal of the American Oil Chemists Society, v. 35 , p.409-412, 1958.

WEISS, W.P. Energy prediction equations for ruminant feeds. In: CORNELL NUTRITION CONFERENCE FOR FEED MANUFACTURERS, 61., 1999. Proceeding... Ithaca: Cornell University, 1999. p.176-185.

WILLIAMS, D.A. A test for differences between treatment means when several dose levels are compared with a zero dose control. Biometrics, v.27, p.103-117, 1971. 